\title{
Adenosine 3',5'-Monophosphate Dependent Protein Kinase of Uterus in Euthyroid and Hypothyroid Rats
}

\author{
Fumitaka KIKKAWA, Takahide NOMURA* and Yasumichi HAGINO* \\ Department of Pharmacology, Nagoya University School of Medicine, \\ Showa-ku, Nagoya 466, Japan \\ *Department of Pharmacology, School of Medicine, Fuịita-Gakuen University. \\ Toyoake 470-11, Aichi, Japan \\ Accepted June 18, 1984
}

\begin{abstract}
Nature of cyclic AMP-dependent protein kinases from the uterus of euthyroid and hypothyroid estrus rats was investigated. There was no significant difference between euthyroid and hypothyroid rats in the protein content and the total activity of cyclic AMP-dependent and independent protein kinases of the soluble fractions of uterus tissues. However it was clearly demonstrated that the type I isozyme remarkably decreased in hypothyroid rats in comparison with that of euthyroid rats. The ratio of type I to type II was 1.26 in euthyroid rats and 0.41 in hypothyroid rats. The kinetic properties of the type I and the type II isozymes from both groups of rats showed similar patterns in NaF, $\mathrm{Mg}^{2+}$, cyclic AMP, histone and ATP. It was not observed that the apparent $K_{m}$ values of both the isozymes for histone and ATP were significantly different between euthyroid and hypothyroid rats. Data obtained from these experiments suggested that the thyroid hormone affected the metabolic processes of the uterus through alteration of the isozyme distribution of cyclic AMP-dependent protein kinase.
\end{abstract}

Phosphorylation of proteins is known to participate profoundly in cellular mechanisms leading to the regulation of various functions and metabolism. Protein kinases are known to depend on cyclic AMP, cyclic GMP, $\mathrm{Ca}^{2+}$ or other agents $(1,2)$. Among these protein kinases, much attention has been placed on cyclic AMP-dependent protein kinase because cyclic AMP is known to be the second messenger of hormones, neuropeptides, and autacoids (3). Cyclic AMP. dependent protein kinase is a tetramer composed of two regulatory subunits and two catalytic subunits. It is well documented that the catalytic subunits are dissociated from the regulatory subunits by cyclic AMP and phosphorylate various kinds of proteins (46). Cyclic AMP-dependent protein kinase has at least two isozymes, type I and type II. The isozyme distribution is variable under various pathological and hormonal environments, although these isozymes seem to be tissue specific. The two isozymes apparently possess the same catalytic subunits, but their regulatory subunits are different.

Thyroid hormone regulates various cellular functions after having been transported to various target organs including the liver. kidney and uterus $(7,8)$. Suggestions have been made that thyroid hormone would regulate cellular functions through the mediation of protein phosphorylation $(9,10)$.

This paper reports the nature of cyclic AMP-dependent protein kinase in the uterus of euthyroid and hypothyroid estrus rats, and it presents evidence for the different distribution of the isozymes between the two thyroid states.

\section{Materials and Methods}

Materials: Histone (type II-A) and propylthyouracil (PTU) were purchased from the Sigma Chemical Co. ATP and adenosine 3', $5^{\prime}$-monophosphate (cyclic AMP) from Boehringer Mannheim. DEAE-cellulose (DE 52) from Whatman. Phosphorus-32 was 
obtained from the Radiochemical Center. Japan. [ $r-32 P] A T P$ was prepared by a modification of the method of Glynn and Chappell (11). Female Wistar rats were fed a $0.15 \%$ PTU diet for over 12 weeks. The hypothyroid status obtained during this period was as reported earlier (12).

Preparation of protein kinase: Female Wistar rats were anesthetized with diethyl ether and then examined on vaginal lavage cytology. Only estrus rats were killed. Then uteri were rapidly removed and quickly chilled in ice-cold $20 \mathrm{mM}$ Tris- $\mathrm{HCl}$ containing $1 \mathrm{mM}$ EDTA $(\mathrm{pH} 7.5)$. Four to five uteri were assembled for a total of over $2 \mathrm{~g}$ and homogenized with 3 volumes of the same buffer. Then the homogenates were centrifuged at $20,000 \times \mathrm{g}$ for $60 \mathrm{~min}$ at $4^{\circ} \mathrm{C}$. Five $\mathrm{ml}$ of supernatant was applied to a DEAE cellulose column $(1 \times 4 \mathrm{~cm})$ which was equilibrated with the same Tris buffer. The column was washed with $50 \mathrm{ml}$ of the same buffer, followed by a linear salt gradient from 0 to $0.4 \mathrm{M}$ sodium chloride containing $20 \mathrm{mM}$ Tris- $\mathrm{HCl}$ and $1 \mathrm{mM}$ EDTA $(\mathrm{pH} 7.5)$. The flow rate was $0.5 \mathrm{ml} / \mathrm{min}$. Five $\mathrm{ml}$ fractions were collected.

Protein kinase assay: The enzyme activity was determined by the method of Corbin et al. (13). The standard reaction mixture contained $20 \mathrm{mM} \mathrm{NaF}, 12.5 \mathrm{mM}$ magnesium acetate, $2 \mathrm{mg} / \mathrm{ml}$ of histone, and $50 \mu \mathrm{l}$ of a solution of potassium phosphate $(17 \mathrm{mM})$ and $\left[\gamma-{ }^{32} \mathrm{P}\right]$ ATP $(0.2 \mathrm{mM})$, in the presence or absence of $2 \mu \mathrm{M}$ of cyclic AMP. The assay reaction was started by adding 20 "ll of the enzyme (total volume, $150 \mathrm{kl}$ ). The incubation was carried out at $30^{\circ} \mathrm{C}$ for $5 \mathrm{~min}$ and then stopped by pipetting $50 /$ aliquots of the reaction mixture onto squares of filter paper $(2 \times 2 \mathrm{~cm})$, followed by washing according to Reimann et al. (14). These papers were dried and transferred to liquid scintillation counting vials to which $10 \mathrm{ml}$ of toluenebased scintillation fluid had been added. Similarly, the type I and the type II isozymes were examined by various concentrations of each component. The protein concentration was determined by the method of Lowry et al. (15).

\section{Results}

Protein kinase activity of soluble fractions: Table 1 shows the protein concentration and the total activity of cyclic AMP-dependent and independent protein kinases of the soluble fractions from euthyroid and hypothyroid rats. There were no significant differences of respective data between euthyroid and hypothyroid rats.

DEAE cellulose column chromatography of soluble fractions: Figure 1 illustrates the DEAE cellulose chromatographic profiles of the soluble fractions from euthyroid and hypothyroid rats. In euthyroid rats, the type I and the type II activities in the presence of cyclic AMP were 334 and 247 pmols $32 \mathrm{P}$ incorporated $/ \mathrm{ml} / \mathrm{min}$ eluted at $0.051 \mathrm{M}$ and $0.13 \mathrm{M} \mathrm{NaCl}$, respectively. In hypothyroid rats, the type I and the type II activities in the presence of cyclic AMP were 103 and 264 pmols $32 \mathrm{P}$ incorporated $/ \mathrm{ml} / \mathrm{min}$ eluted at $0.054 \mathrm{M}$ and $0.13 \mathrm{M} \mathrm{NaCl}$, respectively. The alteration of the type I activities was obviously observed, although the concentration of $\mathrm{NaCl}$ at which the activities eluted

Table 1. Protein kinase activity and protein concentration of soluble fractions from euthyroid and hypothyroid rats

\begin{tabular}{|c|c|c|c|}
\hline & \multicolumn{2}{|c|}{$\begin{array}{c}\text { Protein kinase activity } \\
\text { (pmol }{ }^{32} \mathrm{P} \text { incorporated } / \mathrm{mg} / \mathrm{min} \text { ) } \\
\text { cyclic AMP }\end{array}$} & \multirow[t]{2}{*}{$\begin{array}{l}\text { Protein concentration } \\
(\mathrm{mg} / \mathrm{ml})\end{array}$} \\
\hline & $(+)$ & $(-)$ & \\
\hline $\begin{array}{c}\text { Euthyroid } \\
n=6\end{array}$ & $149 \pm 11$ & $47.9 \pm 3.0$ & $1.6 \pm 0.1$ \\
\hline $\begin{array}{l}\text { Hypothyroid } \\
\quad n=3\end{array}$ & $150 \pm 24$ & $45.4 \pm 3.6$ & $1.6 \pm 0.1$ \\
\hline
\end{tabular}

$(-)$ : in the absence of cyclic AMP. (+): in the presence of 2 " $\mathrm{M}$ cyclic AMP. The data are expressed as the mean \pm S.E. 
was not significantly different between profiles possessed a small third peak. euthyroid and hypothyroid rats. Both of the resembling a shoulder, which eluted at 0.073
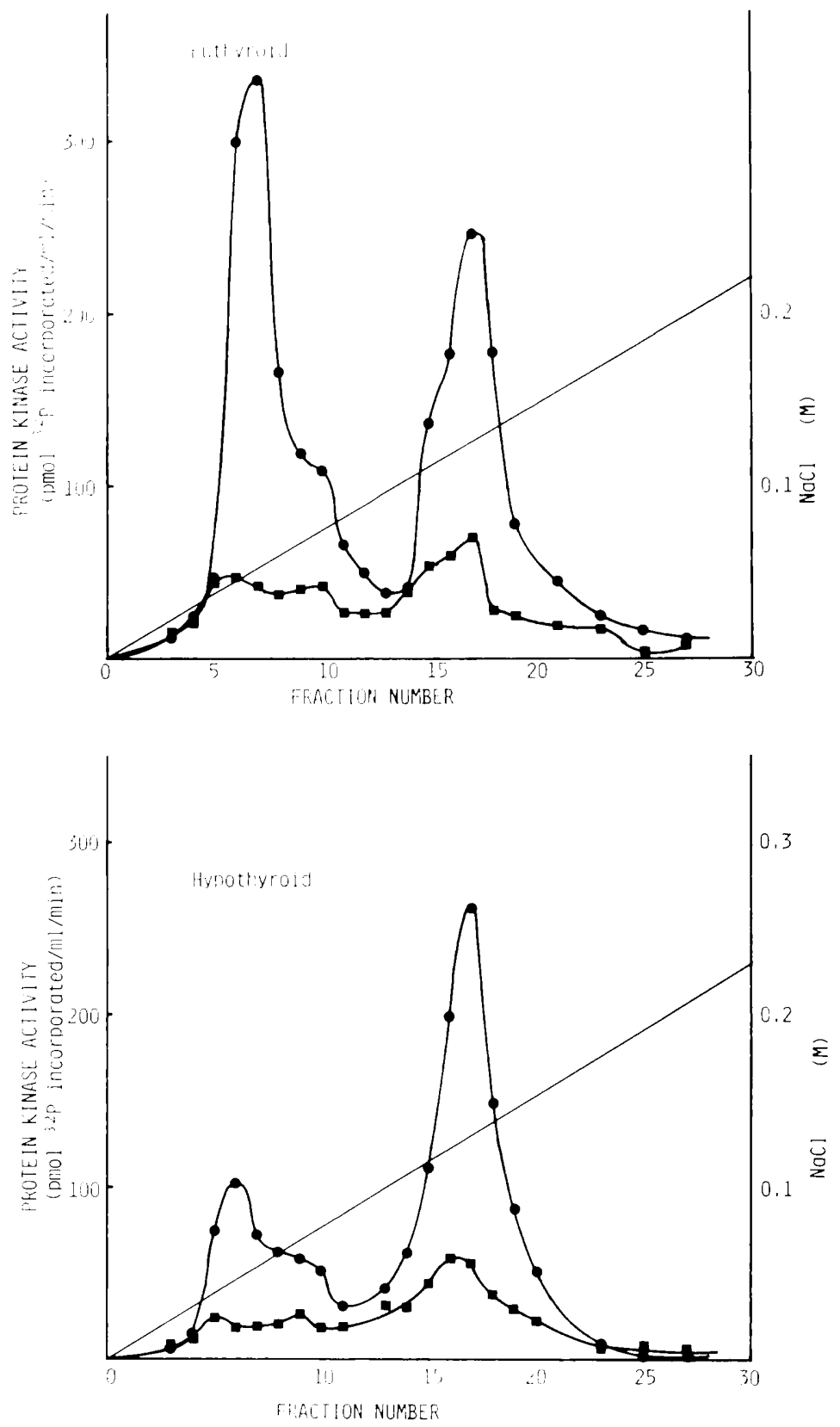

Fig. 1. Elution profiles on the DEAE-celluiose column of protein kinase of uter from euthyroid and hypothyroid rats. Over $2 \mathrm{~g}$ of uteri were homogenized in 3 volumes of $20 \mathrm{mM}$ Tris- $\mathrm{HCl}$ containing $1 \mathrm{mM}$ EDTA $(\mathrm{pH} 7.5)$, and the homogenates were centrifuged at $20,000 \times \mathrm{g}$ for $60 \mathrm{~min}$ at $4^{\circ} \mathrm{C}$. The soluble fractions were chromatographed as described in Materials and Methods. Protein kinase activity was measured in the presence (O) and absence (ם) of $2, M$ cyclic AMP. The activities are given in $\mathrm{pmol}{ }^{32} \mathrm{P}$ incorporated $/ \mathrm{ml} / \mathrm{mmn}$ of fraction. 
$\mathrm{M} \mathrm{NaCl}$ in euthyroid rats and $0.069 \mathrm{M}$ in hypothyroid rats.

Kinetic properties of the type 1 and the type II isozymes: In order to determine the kinetic properties of the type I and the type II

A

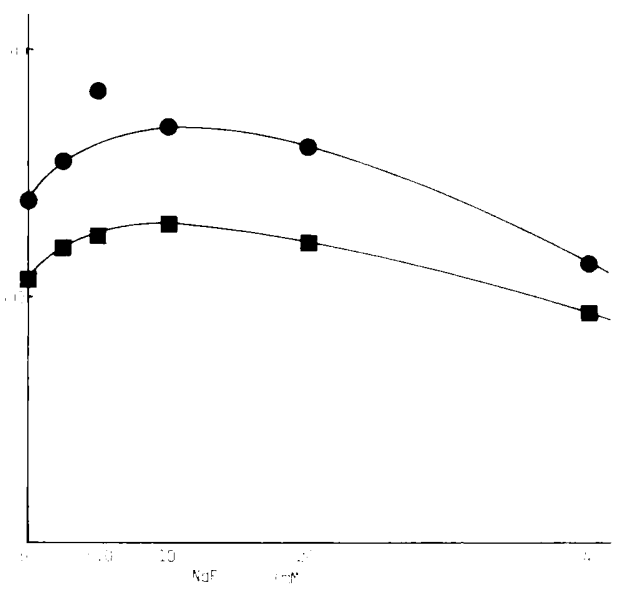

B
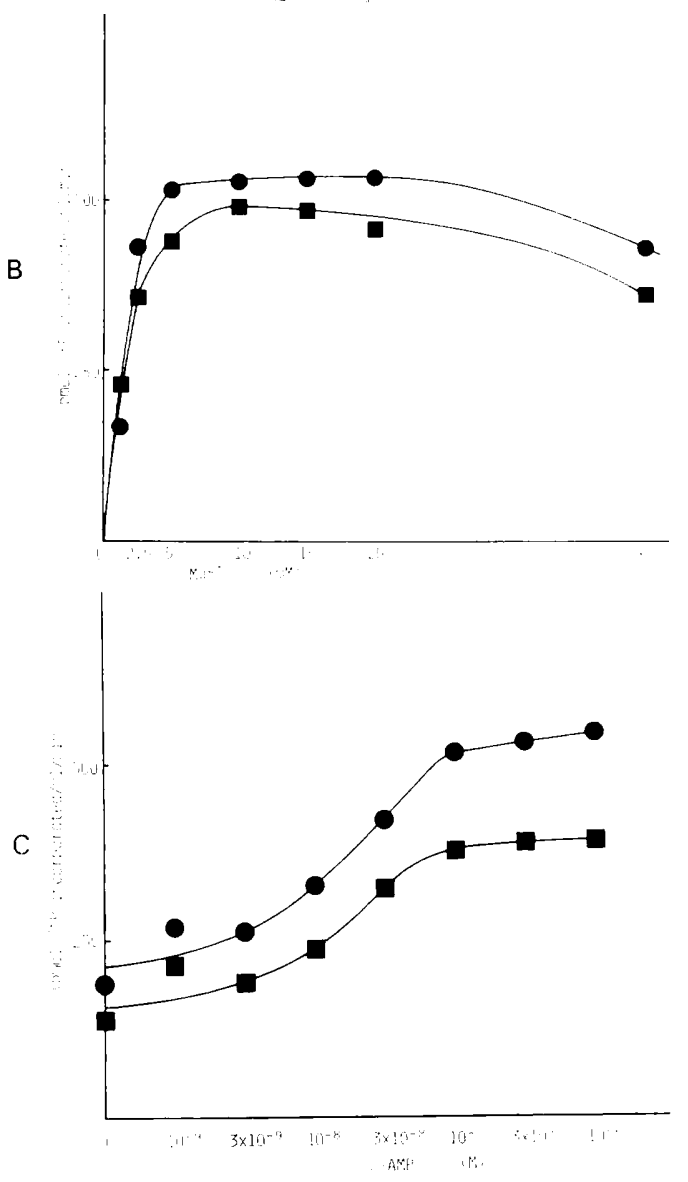

isozymes obtained from euthyroid and hypothyroid rats, the effects of components in the assay system have been investigated. Figure 2A shows the effects of $\mathrm{NaF}$ on the type II isozymes. It was observed that the maximum enzyme activities occured between 5 and $20 \mathrm{mM} \mathrm{NaF}$ in both groups. In the type I isozymes, the maximum enzyme activities also occurred between 5 and $20 \mathrm{mM} \mathrm{NaF}$ in the two thyroid states (Data not shown). Addition of $\mathrm{Mg}^{2+}$ at a concentration up to $5 \mathrm{mM}$ increased the type 11 isozyme activities dose-dependently, and the maximum activities were observed between 10 and $20 \mathrm{mM}$ in both groups of rats (Fig. 2B). In the type I isozymes, the activities increased up to $15 \mathrm{mM}$, and the maximum activities were observed between $15 \mathrm{mM}$ and $20 \mathrm{mM}$ in the two thyroid states (Data not shown). As shown in Fig. 2C, the dose-response curves against cyclic AMP were sigmoid. The marked increase of the enzyme activities occurred from $3 \times 10^{-9}$ to $10^{-7} \mathrm{M}$ cyclic AMP in both the type $\mid$ and the type II isozymes in the two thyroid states. The present data suggest that there were no significant differences of the kinetic properties of the type I and the type II isozymes between both groups of rats.

Apparent $K_{m}$ values of the type I and the type II isozymes: Histone is known to be a good substrate for cyclic AMP-dependent protein kinase. Both the type I and the type II isozyme activities reached the maximum at $1.0 \mathrm{mg} / \mathrm{ml}$ of histone in the two thyroid states (Data not shown). The effects of ATP concentration on the type I and the type II isozyme activities were increased in a dosedependent manner up to $0.1 \mathrm{mM}$ in the two thyroid states (Data not shown). The apparent $K_{m}$ values of the type $I$ and the

Fig. 2. A: Effect of NaF concentration on the type II isozyme from euthyroid (O) and hypothyroid (ם) rats. Protein kinase activity was measured in the presence of $2 \mu \mathrm{M}$ cyclic AMP. B. Effect of $\mathrm{Mg}$ concentration on the type II isozyme from euthyroid (-) and hypothyroid (a) rats. Protein kinase activity was measured in the presence of $2 \mu \mathrm{M}$ cyclic AMP. C: Effect of cyclic AMP concentration on the type II isozyme from euthyroid (O) and hypothyroid $(\mathbf{\square})$ rats. 
Table 2. The apparent $K_{m}$ values of the type I and the type $\|$ for histone and ATP

\begin{tabular}{cccc}
\hline & & $\begin{array}{c}\text { Histone } \\
(\mathrm{mg} / \mathrm{ml})\end{array}$ & $\begin{array}{c}\text { ATP } \\
(\mu \mathrm{M})\end{array}$ \\
Euthyroid & Type I & 0.24 & 22 \\
Hypothyroid & Type II & 0.29 & 23 \\
& Type I & 0.25 & 19 \\
\hline
\end{tabular}

Assays were carried out as described in Materials and Methods. The $K_{m}$ values were calculated by double-reciprocal Lineweaver-Burk plots. Each value is the mean from two experiments carried out in duplicate.

type $\|$ isozymes for histone and ATP are shown in Table 2. The $K_{m}$ values of the type $1 \mathrm{i}$ isozymes for histone and ATP seemed a little larger than that of the type I isozymes in both euthyroid and hypothyroid rats. However, there were no obvious tendency in $K_{m}$ values between euthyroid and hypothyroid rats.

\section{Discussion}

It is well known that the type I and the type 11 isozymes of cyclic AMP-dependent protein kinase can be eluted by DEAE cellulose column chromatography. The ratio of the type I isozyme to the type II isozyme is usually tissue specific (16). It is generally thought that the ratio is larger than 1 in undifferentiated tissues because the type I isozyme is superior to the type II isozyme. On the other hand, in well differentiated tissues, the ratio is smaller than 1 (17). Moreover, the ratio varies with different pathological or hormonal environments (18-22). For example, the type II isozyme in the medulla of hypothyroid rat kidney increased in comparison with that of euthyroid rats (23), Conversely, in the case of skeletal muscle of hypothyroid rats, the type I isozyme increased (12). Furthermore, it was reported by Miyazaki et al. and Matsui et al. $(24,25)$ that the type I isozyme increased by the action of estrogen, whereas the type II isozyme increased by the action of progesterone in both rabbit endometrium and myometrium. In the present study. we observed the alteration of the isozyme distribution and the kinetic properties by using the soluble fractions of uteri from euthyroid and hypothyroid estrus rats. There were clear differences of the isozyme distribution on DEAE cellulose column chromatography: namely, the ratio of the type I to the type $\mid I$ isozyme was 1.26 in euthyroid rats and 0.41 in hypothyroid rats, respectively (Fig. 1). However, no significant difference was observed in the protein content and the total activity of cyclic AMP-dependent protein kinase of the soluble fractions (Table 1). Moreover, there were no remarkable differences of the kinetic properties and the apparent $K_{m}$ values for histone and ATP between euthyroid and hypothyroid rats as shown in Fig. 2 and Table 2. From the result of the present study, it is thought that the decrease in the type I isozyme activity in hypothyroid rats was not due to an alteration of type I isozyme properties, but due to the decrease in the amount of the type I isozyme. In a word, the alteration of the isozyme distribution is due to direct and/or indirect influences of the thyroid hormone on rat uterus and this regulates cellular functions. It has been reported that the nuclei of rat uterine cells possess thyroid hormone receptor, which amounts to about $1 / 3$ of that of liver and $1 / 2$ of that of kidney (26). Therefore, it is reasoned that a uterus is one of the target tissues of thyroid hormone. Thyroid hormone, which has various target tissues, has broad influences on metabolism, growth and differentiation (7, 8, 27). Combest and Russell (9) and Nakamura et al. (10) reported that the effect of thyroid hormone has influences on both phosphorylation and dephosphorylation in rat liver. Therefore, it is likely that protein kinase plays an important role in the effects of thyroid hormone. Mednieks et al. (28) reported that cyclic AMP-dependent protein kinase was redistributed between the cytoplasm and intranuleus by theophylline in 
leukemia L 1210 cells. Unfortunately, it is not clear in the present research whether the change of the isozyme distribution is caused by the translocation, synthesis or the breakdown of the isozymes, and the physiological role of the decrease in the type I isozyme activity of hypothyroid rats still remains an open question. Further investigation will be made with regard to these points.

\section{References}

1 Cohen, P.: The role of protein phosphorylation in neural and hormonal control of cellular activity. Nature 296, 613-619 (1982)

2 Hamet, P.: Cyclic nucleotides in clinical phar macology. Trends Pharmacol. Sci. 45, 218-221 (1983)

3 Bartfai, T.: Cyclic nucleotides and the nervous system. Trends Pharmacol. Sci. 36, 338-340 (1982)

4 Gill, G.N. and Garren, L.D.: A cyclic-3',5'adenosine monophosphate dependent protein kinase from the adrenal cortex: comparison with a cyclic AMP binding protein. Biochem. Biophys. Res. Commun. 39, 335-343 (1970)

5 Kumon, A., Yamamura, $H$. and Nishizuka, $Y$.: Mode of action of adenosine $3^{\prime}, 5^{\prime}$-cyclic phos phate on protein kinase from rat liver. Biochem. Biophys. Res. Commun. 41, 1290-1297 (1970)

6 Tao, M., Salas, M.L. and Lipmann, F.: Mechanism of activation by adenosine $3^{\prime}: 5^{\prime}$-cyclic monophosphate of a protein phosphokinase from rabbit reticulocytes. Proc. Natl. Acad. Sci. U.S.A. 67, 408-414 (1970)

7 Gardner, R.M., Kirkland, J.L., Ireland, J.S. and Stancel, G.M.: Regulation of the uterine response to estrogen by thyroid hormone. Endocrinology 103, 1164-1172 (1978)

8 Muller, M.J. and Seitz, H.J.: Interaction of thyroid hormones and cyclic AMP in the stimu lation of hepatic gluconeogenesis. Biochim Biophys. Acta 756, 360-368 (1983)

9 Combest, W.L. and Russell, D.H.: Alteration in cyclic AMP-dependent protein kinases and polyamine biosynthetic enzymes during hypertrophy and hyperplasia of the thyroid in the rat. Mol. Pharmacol. 23, 641-647 (1982)

10 Nakamura, H., Rue, P.A. and DeGroot, L.J.: Thyroid hormone increases type I adenosine $3^{\prime} 5^{\prime}$-monophosphate-dependent protein kinase and casein kinase activities in rat liver cytosol Analysis of protein kinases by polyacrylamide disc gel electrophoresis. Endocrinology 112 , $1427-1433(1983)$
11 Glynn, I.M. and Chappell, J.B.: A simple method for the preparation of ${ }^{32} \mathrm{P}$-labelled triphosphate of high specific activity. Biochem. J. 90, 147$149(1964)$

12 Hagino, $Y$. and Tachibana, M. Effect of hypothyroid status on adenosine 3'.5'-monophosphate-dependent protein kinase of skeletal. heart, and diaphragm muscle of rats. Japan. J. Pharmacol. 31, 1005-1012 (1981)

13 Corbin, J.D., Solderling, T.R. and Park, C.R.: Regulation of adenosine $3^{\prime}, 5^{\prime}$-monophosphatedependent protein kinase I. Preliminary characterzation of the adipose tissue enzyme in crude extracts. J. Biol. Chem. 248, 1813-1821 (1973)

14 Reimann, E.M., Walsch, D.A. and Krebs, E.G. Purification and properties of rabbit skeletal muscle adenosine 3',5'-monophosphatedependent protein kinases. J. Biol. Chem. 246, 1986-1995 (1971)

15 Lowry, O.H., Rosebrough, N.J., Farr, A.L, and Randall, R.J.: Protein measurement with the Folin phenol reagent. J. Biol. Chem. 193, 265$275(1951)$

16 Nimmo, H.G. and Cohen, P.: Hormonal control of protein phosphorylation. Adv. Cyclic Nucleotide Res. 8, 145-266 (1977)

17 Russell, D.H.: Type 1 cyclic AMP-dependent protein kinase as a positive effector of growith. Adv. Cyclic Nucleotide Res. 9, 493-506 (1978)

18 Hagino, $Y$., Uematsu, $T$. and Tachibana, $M$ : Effects of phenylephrine arid isopreterenol on the activity of cyclic AMP-dependent protein kinase of hypothyroid rat tissues. Japan. J. Pharmacol. 29, 889-898 (1979)

19 Hagino, Y., Uematsu, T., Tachibana, M. and Tsuru. H.: Effect of thyroid hormone on cyclic AMP phosphodiesterase in rat kidney. Japan. J. Pharmacol. 30, 521-528 (1980)

20 Miyazaki, K., Miyamoto, E., Maeyama, M. and Uchida, M.: Specific regulation by steroid hormones of protein kinases in the endometrium. Eur. J. Biochem. 104, 543-547 (1980)

21 Miyazaki, K., Matsui, K., Maeyama, M. and Miyamoto, E.: Regulation by human chorionic gonadotropin of protein kinases in rabbit. Biochim. Biophys. Acta 677, 120-125 (1981)

22 Majumder, G.C.: Protein kinase activity in mouse mammary carcinoma. Biochem. Biophys. Res. Commun. 74, 1140-1145 (1977)

23 Hagino, Y., Uematsu, T. and Tachibana, M.: Effect of hypothyroid status on adenosine $3^{\prime}, 5^{\prime}$ monophosphate-dependent protein kinases of rat kidney. Japan. J. Pharmacol. 31, 185-192 (1981)

24 Miyazaki, K., Miyamoto, E., Maeyama, M. and 
Uchida, M.: Specific regulation by sterold hormones of protein kinases in the endometrium. Eur. J. Biochem. 104, 535-542 (1980)

25 Matsui, K., Higashi, K., Miyazaki, K., Fukunaga, K., Maeyama, M. and Miyamoto, E.: Regulation by estrogen and progesterorie of protein kinases in rabbit myometrium. Japan. J. Pharmacol. 33, 385-393 (1983)

26 Evans, R.W., Farwell, A.P. and Braverman, L.E.: Nuclear thyroid hormone receptor in the rat uterus. Endocrinology 113, 1459-1463 (1983)

27 Cidlowsky, J.A. and Muldoon, T.G.: Modulation by thyroid hormones of cytopasmic tissues of the rat. Endocrinology 97, 59-67 (1975)

28 Mednieks, M.I., Jungmann, R.A. and DeWys, W.D.: Cyclic adenosine $3^{\prime}: 5^{\prime}$-monophosphatedependent protein phosphorylation and the control in leukemia L 1210 cell growth. Cancer Res. 42, 2742-2747 (1982) 